\title{
Changes in mineral nutrition during fruit growth and development of 'Seike' and 'Newhall' navel orange as a guide for fertilization
}

\author{
Xing-Zheng $\mathrm{Fu}^{1}$, Fa Xie ${ }^{2}$, Li Cao ${ }^{3}$, Li-Li Ling ${ }^{4}$, Chang-Pin Chun ${ }^{5}$, Liang-Zhi Peng ${ }^{6}$ \\ Abstract - Changes in the accumulation patterns of mineral nutrients at different development \\ stages of fruit reflect the requirements of citrus trees for different nutrients, and this information \\ provides an essential reference for rational fertilization. In this study, changes in the contents of \\ 11 nutrients in the whole fruit, fruit pulp, and peel were studied during the whole developmental \\ period of the fruit of 'Seike' and 'Newhall' navel oranges. We found that the two navel orange \\ cultivars showed very similar changes in nutrients. Specifically, the N, P, Mg, S, Mn, and Zn \\ contents were high in the young fruit stage (April), the $\mathrm{K}$ and $\mathrm{Fe}$ contents were high in the fruit \\ expansion stage (July and August), and the Ca content was high in the fruit maturation stage \\ (October). As the fruit developed, the $\mathrm{N}, \mathrm{P}, \mathrm{Mg}, \mathrm{S}, \mathrm{Zn}$, and B contents decreased to the lowest \\ levels at fruit maturity in November. In addition, the contents of $\mathrm{N}, \mathrm{P}, \mathrm{K}, \mathrm{Fe}, \mathrm{Zn}$, and $\mathrm{Cu}$ were \\ ranked as fruit pulp $>$ whole fruit $>$ peel, while $\mathrm{Ca}, \mathrm{Mn}$, and $\mathrm{B}$ contents were ranked as fruit peel \\ $>$ whole fruit > fruit pulp. N, P, K, and Mg accumulated in the fruit in June and July, in contrast \\ to the June to September period for the micro-elements. During these accumulation periods, it is \\ recommended that suitable fertilizers be applied in a timely manner. \\ Index terms: Citrus, fruit pulp, peel, mineral nutrition.

\section{Mudanças na nutrição mineral durante o crescimento do fruto e desenvolvimento de laranja baía dos cultivares 'Seike' e 'Newhall' como guia para fertilização}

Corresponding author: pengliangzhi@cric.cn

Received: April 30, 2019 Accepted: August 16, 2019

Copyright: All the contents of this journal, except where otherwise noted, is licensed under a Creative Commons Attribution License.

(cc) $\mathrm{EY}$
Resumo - Mudanças nos padrões de acumulação de nutrientes minerais em diferentes estágios de desenvolvimento do fruto refletem as exigências de plantas cítricas para diferentes nutrientes, e essa informação fornece uma referência essencial para a fertilização racional. Neste estudo, mudanças no conteúdo de 11 nutrientes no fruto inteiro, na polpa e na casca foram estudadas durante todo o período de desenvolvimento do fruto de laranjas-baía das cultivares "Seike" e "Newhall". Descobriu-se que as duas cultivares mostraram mudanças muito semelhantes em relação aos nutrientes. Especificamente, os teores de N, P, Mg, S, Mn e Zn foram elevados no estágio de frutos jovens (abril), os teores de $\mathrm{K}$ e Fe foram elevados no estágio de expansão de frutos (julho e agosto) e o conteúdo de Ca foi elevado no estágio de maturação de frutos (outubro). À medida que os frutos se desenvolveram, os teores de $\mathrm{N}, \mathrm{P}, \mathrm{Mg}, \mathrm{S}, \mathrm{Zn}$ e $\mathrm{B}$ atingiram os menores teores no estágio de maturação dos frutos em novembro. Além disso, os teores de $\mathrm{N}, \mathrm{P}, \mathrm{K}, \mathrm{Fe}, \mathrm{Zn}$ e $\mathrm{Cu}$ foram classificados de forma decrescente como: polpa $>$ fruto inteiro $>$ casca, enquanto os teores de $\mathrm{Ca}$, Mn e B foram classificados como: casca > fruto inteiro> polpa. N, P, K e Mg acumularam -se na fruta, em junho e julho, em contraste com o período de junho a setembro. Durante esses períodos de acumulação, recomenda-se que fertilizantes adequados sejam aplicados em tempo oportuno.

Termos para indexação: Cítrus, polpa de fruta, casca, nutrição mineral.

${ }^{1}$ Associate Professor, Citrus Research Institute, Southwest University/ Chinese Academy of Agricultural Sciences, Chongqing, China. Email: fuxingzheng@cric.cn (ORCID 0000-0003-4088-6443)

${ }^{2}$ Master Student, Citrus Research Institute, Southwest University/ Chinese Academy of Agricultural Sciences, Chongqing, China. Email: 276310885@qq.com (ORCID 0000-0002-2130-8974)]

${ }^{3}$ Associate Professor, Citrus Research Institute, Southwest University/ Chinese Academy of Agricultural Sciences, Chongqing, China. Email: caoli@eric.cn (ORCID 0000-0001-5022-6778)

${ }^{4}$ Associate Professor, Citrus Research Institute, Southwest University/ Chinese Academy of Agricultural Sciences, Chongqing, China. Email: linglili@cric.cn (ORCID 0000-0002-9697-3469)

${ }^{5}$ Associate Professor, Citrus Research Institute, Southwest University/ Chinese Academy of Agricultural Sciences, Chongqing, China. Email: chunchangpin@cric.cn (ORCID 0000-0001-7955-9568)

${ }^{6}$ Professor, Citrus Research Institute, Southwest University/ Chinese Academy of Agricultural Sciences, Chongqing , China. Email: pengliangzhi@cric.cn(ORCID 0000-0003-1620-027X) 


\section{Introduction}

Mineral nutrients determine the growth, development, yield, and quality of fruit trees (ALVA et al., 2006; RAZZAQ et al., 2013; BRUNETTO et al., 2015; ZHOU et al., 2018). Nutrient deficiency or excess will cause poor growth of citrus trees as well as low yield and fruit quality. To diagnose the nutritional status of citrus trees and to quantify fertilization, leaf and soil analyses have been well established. Leaf analysis is the most accurate indicator of fruit crop nutritional status (ZEKRI et al., 2005; OBREZA; MORGAN, 2008). Many studies have reported the seasonal changes in mineral nutrients of citrus leaves (ZHOU et al., 2004; XIAO et al., 2007; SHENG et al., 2009; MIRSOLEIMANI et al., 2014). Indeed, apart from leaf and soil analysis, target yield fertilization is another important method. This is because a large proportion of mineral nutrients accumulates in the fruit and is removed during harvesting. The application amount of fertilizer can be calculated according to the nutrition concentration of fruit and the target yield (ZEKRI et al., 2005; OBREZA; MORGAN, 2008). For example, the $\mathrm{N}$ concentration in grapefruit (Citrus paradisi) and sweet orange (Citrus sinensis) fruit ranges from $0.11 \%$ to $0.18 \%$, and the application of $\mathrm{N}$ is about 2.5 to 3 times the $\mathrm{N}$ content of fruit in the USA. This means that 3.3 to $4.5 \mathrm{~kg}$ of elemental $\mathrm{N}$ needs to be applied for each $1000 \mathrm{~kg}$ of fruit produced in a grapefruit or sweet orange orchard (ZEKRI et al., 2005; PARSONS; BOMAN, 2006; OBREZA; MORGAN, 2008).

Although the mineral nutrition of citrus fruits has been studied in many reports, most of the studies have focused on the influence of mineral nutrition on fruit yield and quality (ALVA et al., 2006; HAMMAMI et al., 2010; RAZZAQ et al., 2013; ZHOU et al., 2018), and on physiological disorders, such as peel wrinkling and fruit cracking (CHEN et al., 2002; STOREY et al., 2002; TREEBY; STOREY, 2002; XIAO et al., 2006; SHENG et al., 2009; MA et al., 2011; LI; CHEN, 2017). In addition, previous studies have also been conducted to analyze the total contents of nutrients in fruit and the total requirements of citrus trees with respect to mineral nutrition (OBREZA; MORGAN, 2008; ROCCUZZO et al., 2012). Indeed, citrus trees have different requirements for each element at the different fruit growth and development stages, but limited information is available. The aims of this study were to provide better information regarding the change and accumulation of nutrient elements during different fruit growth and developmental stages. This information can help to guide more accurate fertilization together with leaf and soil analysis in citrus management practice.

\section{Materials and Methods}

\section{Locations and Materials}

Experiments were performed in 2010 on 'Seike' navel orange (Citrus sinensis Osbeck cv 'Seike') and 'Newhall' navel orange (Citrus sinensis Osbeck cv 'Newhall') trees grafted on trifoliate orange (Poncirus trifoliata L. Raf.) rootstocks, which were grown in the same orchard of the Citrus Research Institute, Southwest University (Chongqing, China). Trees were planted in spring 1985 at a spacing of $5 \mathrm{~m} \times 4 \mathrm{~m}$, and the same management practices were carried out. For fertilization in 2008, 2009 and 2010, $500 \mathrm{~g}$ urea per tree $(\mathrm{N} \geq 46.4 \%)$ was applied at February, March, April, July, and September (100 g each month) annually; $1000 \mathrm{~g}$ of $45 \%$ compound fertilizer (N:P:K=15:15:15) per tree was applied at June annually; $0.5 \%$ of $\mathrm{KH}_{2} \mathrm{PO}_{4}$ was foliar applied at August, September, and October annually; and approximately 10 $\mathrm{kg}$ of organic fertilizer per tree was applied at December annually. The nutrient levels of soil in 2010 were available $\mathrm{N} 78.1 \mathrm{mg} \mathrm{kg}^{-1}, \mathrm{P} 20.0 \mathrm{mg} \mathrm{kg}^{-1}, \mathrm{~K} 80.0 \mathrm{mg} \mathrm{kg}^{-1}$, Ca 2042.8 $\mathrm{mg} \mathrm{kg}^{-1}, \mathrm{Mg} 244.0 \mathrm{mg} \mathrm{kg}^{-1}$, S $17.9 \mathrm{mg} \mathrm{kg}^{-1}$, Fe $20.1 \mathrm{mg}$ $\mathrm{kg}^{-1}$, Mn $48.5 \mathrm{mg} \mathrm{kg}^{-1}$, Zn $5.2 \mathrm{mg} \mathrm{kg}^{-1}$, Cu $1.6 \mathrm{mg} \mathrm{kg}^{-1}$, B $0.5 \mathrm{mg} \mathrm{kg}^{-1}$, and organic matter $12.8 \mathrm{~g} \mathrm{~kg}^{-1}$. The $\mathrm{pH}$ of the soil varies from 6.0 to 6.5 . For pest and disease control, abamectin, acetamiprid, and dithane were applied 3-5 times per year. The orchard has purple soil and is classified as a Pup-Orthic Entisol in the Chinese soil taxonomy and as an Entisol in the U.S. taxonomy (GONG, 1999). In 2010 , the productivity per tree was about $40 \mathrm{~kg}$, and the trees reached full bloom around April 12; the first and second physiological fruit drop ended in mid-May and mid-June, respectively. To analyze the change and accumulation of nutrient element contents during fruit growth and development, 15 uniform trees were selected randomly and divided into three blocks/repeats ( 5 trees per block/repeat). In total, 30 fruits were sampled per block on July 26, August 28, September 30, October 27, and November 30, while 50 fruits were sampled on April 30, May 28, and June 30 due to the small fruit size at the time of sampling. To facilitate understanding of these sampling times in the results, these periods were divided into the young fruit stage (April to June), fruit expansion stage (July to August), and fruit maturation stage (September to November).

\section{The measurement of nutrient element contents}

The sampled fruits were washed, and then the fruit pulp and peel were separated to measure the nutrient element contents in these two parts except for the fruits sampled on April 30, May 28, and June 30, due to the small fruit size. The fruit pulp and peel were difficult to separate, and the nutrient elements in the whole fruit were measured for these parts. Subsequently, the samples were stoved, weighed, and pulverized. About $0.5 \mathrm{~g}$ of powder 
was digested in $10 \mathrm{~mL}$ of a $5: 1(\mathrm{v} / \mathrm{v})$ mixed solution of concentrated $\mathrm{HNO}_{3}$ and $\mathrm{HClO}_{4}$ at $165^{\circ} \mathrm{C}$ for $4 \mathrm{~h}, 185^{\circ} \mathrm{C}$ for $2 \mathrm{~h}$, and $206^{\circ} \mathrm{C}$ for $2.5 \mathrm{~h}$ to measure 9 elements: $\mathrm{P}, \mathrm{K}$, $\mathrm{Ca}, \mathrm{Mg}, \mathrm{S}, \mathrm{Fe}, \mathrm{Mn}, \mathrm{Zn}$, and $\mathrm{Cu}$. The $\mathrm{K}, \mathrm{Ca}, \mathrm{Mg}, \mathrm{Fe}, \mathrm{Mn}$, $\mathrm{Zn}$, and $\mathrm{Cu}$ were determined using an atomic adsorption spectrophotometer (Perkin-Elmer AA800, USA), while P and $\mathrm{S}$ were determined using a TU-1901 spectrophotometer (Purkinje General Instrument Ltd Company, China). For $\mathrm{N}, 0.1 \mathrm{~g}$ of powder was digested in $5 \mathrm{~mL}$ of concentrated $\mathrm{H}_{2} \mathrm{SO}_{4}$ under catalysis of a 10:1 (W/W) mixture of $\mathrm{K}_{2} \mathrm{SO}_{4}$ and $\mathrm{CuSO}_{4}$ followed by measurement using the Kjeldahl method with a Kjeldahl analyzer (KDY-9820, KETUO, China). For B, $0.5 \mathrm{~g}$ of powder was first infiltrated with $2 \mathrm{~mL}$ of saturated $\mathrm{Ca}(\mathrm{OH})_{2}$; after ashing, the dry-ash was digested in $10 \mathrm{~mL}$ of $0.18 \mathrm{M} \mathrm{H}_{2} \mathrm{SO}_{4}$ and measured with a TU-1901 spectrophotometer (Purkinje General Instrument Ltd Company, China).

The measurement of fruit fresh and dry weight

To study the accumulation of each nutrient at different development stages of the fruit, the fresh and dry weight per fruit were measured from April 30 to November 30. Briefly, 30 or 50 fruits were first weighted using an electronic balance when sampled at each month to calculate their fresh weight. After the separated fruit pulp and peel were stoved until constant weight, their dry weights were measured using electronic balance. Dry weight per fruit were calculated as sum of dry weight of fruit pulp and peel, while increment in fresh and dry weight per fruit in each month were calculated as the difference between two subsequent months.

\section{Data Analysis}

The data presented are the mean values \pm standard errors (SE). Statistical analysis of the data was performed using SAS software (SAS Institute Inc., Cary, NC, USA). The Least Significant Differences (LSD) test was used to compare the differences among mean values at $5 \%$ level.

\section{Results and Discussion}

\section{Changes in nutrient element contents during fruit growth and development}

The contents of macro-elements (N, P, K, Ca, Mg, and $\mathrm{S}$ ) are shown in Figure 1. Generally, the 'Seike' and 'Newhall' exhibited very similar results, except K contents in fruit pulp and peel. In the whole fruit of both 'Seike' and 'Newhall', the contents of N, P, and Mg continuously decreased from April 30 to November 30 while K increased first and then decreased as the fruit developed; the peak K occurred during the fruit expansion stage (July 26 in 'Seike' and September 30 in 'Newhall'). The N, P, and $\mathrm{Mg}$ contents in the fruit pulp and peel of both 'Seike' and 'Newhall' also continuously decreased from July 26 to November 30, similar to those in the whole fruit. The $\mathrm{Ca}$ and $\mathrm{S}$ contents in the whole fruit of both 'Seike' and 'Newhall' were irregular during the fruit development period, and the highest content of $\mathrm{Ca}$ occurred in the fruit maturation stage (October 27) in contrast to the young fruit stage for the $\mathrm{S}$ content (April 30). In fruit pulp, the $\mathrm{Ca}$ and $\mathrm{S}$ tended to stabilize (except $\mathrm{Ca}$ in 'Newhall') while in the peel, the $\mathrm{Ca}$ exhibited an increased trend from July 26 to November 30.

The contents of micro-elements ( $\mathrm{Fe}, \mathrm{Mn}, \mathrm{Zn}, \mathrm{Cu}$, and B) are shown in Figure 2. There were also very similar results between 'Seike' and 'Newhall', except Mn contents at fruit maturation stage. Specifically, the Fe content in the whole fruit of both 'Seike' and 'Newhall' was stable in the young fruit stage (from April 30 to June 30) but increased sharply in the fruit expansion stage (July 26), and then gradually declined to a low value. In the peel of both 'Seike' and 'Newhall', Fe showed no significant difference at all time points, but it continuously decreased in the fruit pulp from July 26 to November 30 . The Mn and Zn contents in the whole fruit of both 'Seike' and 'Newhall' decreased significantly in the young fruit stage (from April 30 to June 30) and then showed an increase on August 28 and July 26, respectively. In the subsequent fruit development stages, Mn gradually declined again until October 27 for 'Seike' and November 30 for 'Newhall', whereas Zn was stable. In the fruit pulp and peel, Mn increased first and then decreased, but a sharp increase occurred at the maturity stage of 'Seike'. The Zn contents in the fruit pulp and peel of both 'Seike' and 'Newhall' were almost stable during the fruit development period. From April 30 to June 30 , the $\mathrm{Cu}$ content in the whole fruit of both 'Seike' and 'Newhall' decreased sharply but recovered on July 26 and stabilized in the later development period. In the fruit pulp and peel of both 'Seike' and 'Newhall', the $\mathrm{Cu}$ contents showed very small changes. In general, the changes in the B contents in the whole fruit, fruit pulp and peel of two cultivars were inconspicuous during fruit growth and development. However, in the whole fruit, the higher B contents mainly occurred in the young fruit period (from April 30 to June 30), while lower B contents mainly occurred in the maturation period (from October 27 to November 30).

A comparison of these element contents among the whole fruit, fruit pulp and peel indicated that $\mathrm{N}, \mathrm{P}, \mathrm{K}, \mathrm{Fe}$, $\mathrm{Zn}$, and $\mathrm{Cu}$ were ranked as fruit pulp $>$ whole fruit $>$ peel, and $\mathrm{Ca}, \mathrm{Mn}$ and $\mathrm{B}$ were ranked as peel $>$ whole fruit $>$ fruit pulp, whereas $\mathrm{Mg}$ and S showed no obvious difference in both 'Seike' and 'Newhall' (Fig. 1 and Fig. 2). Taken together, these results show that in the whole fruit, high contents of $\mathrm{N}, \mathrm{P}, \mathrm{Mg}, \mathrm{S}, \mathrm{Mn}, \mathrm{Zn}$, and B occurred in the young fruit stage, those of $\mathrm{K}$ and $\mathrm{Fe}$ occurred during the fruit expansion stage, and that of $\mathrm{Ca}$ occurred during the fruit maturation stage. By contrast, low contents of N, P, $\mathrm{Mg}, \mathrm{S}, \mathrm{Mn}, \mathrm{Zn}$, and $\mathrm{B}$ occurred during the fruit maturation 
stage, and those of $\mathrm{Fe}$ and $\mathrm{Ca}$ occurred during the young fruit stage. In the fruit pulp, high contents of $\mathrm{N}, \mathrm{K}, \mathrm{Mg}$, $\mathrm{Fe}, \mathrm{Mn}, \mathrm{Zn}$ and $\mathrm{Cu}$ occurred during the fruit expansion stage, and low contents of $\mathrm{K}, \mathrm{Mg}, \mathrm{Fe}, \mathrm{Mn}$, and $\mathrm{Zn}$ occurred during the fruit maturation stage, whereas $\mathrm{P}, \mathrm{S}, \mathrm{Ca}$, and $B$ were stable. In the fruit peel, high contents of $\mathrm{N}, \mathrm{P}, \mathrm{K}$, and $\mathrm{Mg}$ occurred during the fruit expansion stage, and those of $\mathrm{Ca}$, and $\mathrm{Cu}$ occurred during the fruit maturation stage. Low contents of $\mathrm{N}, \mathrm{P}, \mathrm{K}$, and $\mathrm{Mg}$ occurred during the fruit maturation stage, and those of $\mathrm{Ca}, \mathrm{Fe}, \mathrm{Mn}$, and $\mathrm{Cu}$ occurred during the fruit expansion stage, whereas $\mathrm{P}$, $\mathrm{S}, \mathrm{Zn}$, and B were stable.

Fresh and dry weight of fruit during growth and development

As shown in Figure 3, the increase in fresh weight was slow in the young fruit stage (from April 30 to June 30 ) and then showed a rapid increase from the fruit expansion stage (July 26) to the maturation stage (October 27) in both 'Seike' and 'Newhall'. The dry weight increased continuously during the whole fruit development stage although the rate of increase was significantly slower than that of fresh weight (Fig. 3A). The monthly increases of fresh and dry weight per fruit increased and then decreased, and the highest increases in fresh and dry weight occurred on August 28 for 'Seike', 30 September 30 for 'Newhall', and June 30 for 'Seike', August 28 for 'Newhall', respectively (Fig. 3B). During the last month of the maturation stage (from October 27 to November 30 ), the increases of both fresh and dry weight were very low, similar to those during the young fruit stage.

\section{Accumulation of nutrient elements during fruit} growth and development

As shown in Figure 4, the 'Seike' and 'Newhall' showed very similar accumulation patterns of nutrient elements during fruit growth and development. Taken 'Seike' for instance, the monthly accumulation of N, P, $\mathrm{K}, \mathrm{Ca}, \mathrm{Mg}$, and $\mathrm{S}$ per fruit was rapid in the young fruit stage (from May 28 to June 30). The accumulation of these elements in May was 2.0 (P) to $6.3(\mathrm{~K})$ times that in April, and in June was $4.8(\mathrm{Mg})$ to $31.0(\mathrm{Ca})$ times that in May. However, after June, the monthly accumulation of these elements decreased. The highest monthly accumulation of $\mathrm{N}, \mathrm{P}, \mathrm{K}, \mathrm{Mg}$, and $\mathrm{S}$ occurred in June, and that of $\mathrm{Ca}$ occurred in August ('Seike') or October ('Newhall'). The important accumulation times of $\mathrm{N}, \mathrm{P}, \mathrm{K}$, and $\mathrm{Mg}$ were June and July, while that of Ca was August and October, whereas that of S was June and September. The monthly accumulation of micro-elements, $\mathrm{Mn}$ and $\mathrm{B}$, showed similar trends as those of macro-elements, i.e., a rapid increase during the young fruit stage (from May 28 to June 30) and a reduction from July onwards (Fig. 4). The accumulation of Fe occurred mainly in July, that of $\mathrm{Zn}$ in June and July, and that of $\mathrm{Cu}$ in July and October
(Fig. 4). In general, June to September was the important accumulation period of micro-elements (Fig. 4).

The total accumulation of nutrient elements in the fruit reflects the total demands of citrus trees for different mineral nutrients during the whole period of fruit growth and development. As shown in Figure 4, the total accumulation of $\mathrm{N}$ and $\mathrm{K}$ reached $500-600 \mathrm{mg}$ per fruit, followed by $\mathrm{Ca}$ (200-300 mg per fruit). Among the microelements, the total accumulation of Fe and $\mathrm{B}$ was 2000-2500 and 1100-1500 $\mu \mathrm{g}$ per fruit, respectively (Fig. 4).

In this study, the changes in mineral nutrition during fruit growth and development were analyzed in two different navel orange cultivars. Interestingly, the two cultivars showed amazing consistency in variation tendency of nutrients. When comparing the nutrient contents of the fruit with reference values of previous studies, they are also in close ranges. For example, the content ranges of $\mathrm{P}(0.10 \%-0.31 \%), \mathrm{K}(0.99 \%-1.41 \%)$, $\mathrm{Mg}(0.08 \%-0.23 \%), \mathrm{Ca}(0.09 \%-0.55 \%), \mathrm{S}(0.06 \%-0.13 \%)$, Fe (31.6-74.8 $\left.\mathrm{mg} \mathrm{kg}^{-1} \mathrm{DW}\right), \mathrm{Mn}\left(5.7-13.1 \mathrm{mg} \mathrm{kg}^{-1} \mathrm{DW}\right)$, $\mathrm{Zn}$ (4.9-12.5 mg kg-1 DW), Cu (1.8-5.2 $\left.\mathrm{mg} \mathrm{kg}^{-1} \mathrm{DW}\right)$, and B (29.1-36.5 mg kg-1 DW) in whole fruit of 'Seike' agree well with those reported in whole fruit of 'Bellamy' navel orange: $\mathrm{P}(0.08 \%-0.25 \%), \mathrm{K}(0.78 \%-1.56 \%), \mathrm{Mg}$ (0.07\%-0.19\%), Ca (0.20\%-0.80\%), S (0.06\%-0.16\%), Fe (19.5-58.6 mg kg-1 DW), Mn (2.2-11.1 $\left.\mathrm{mg} \mathrm{kg}^{-1} \mathrm{DW}\right)$, $\mathrm{Zn}$ (5.2-16.3 $\left.\mathrm{mg} \mathrm{kg}^{-1} \mathrm{DW}\right), \mathrm{Cu}\left(1.9-5.7 \mathrm{mg} \mathrm{kg}^{-1} \mathrm{DW}\right)$, and B (18.4-31.3 $\left.\mathrm{mg} \mathrm{kg}^{-1} \mathrm{DW}\right)$, by Storey and Treeby (2000). They also agree well with the reported data in fruit peel of 'Newhall' navel orange: K (0.90\%-1.30\%), Mg (0.06\%$0.13 \%), \mathrm{Ca}(0.40 \%-0.80 \%)$, Fe (20.0-45.0 $\left.\mathrm{mg} \mathrm{kg}^{-1} \mathrm{DW}\right)$, Mn (6.0-9.1 $\left.\mathrm{mg} \mathrm{kg}^{-1} \mathrm{DW}\right), \mathrm{Zn}\left(11.8-17.0 \mathrm{mg} \mathrm{kg}^{-1} \mathrm{DW}\right)$, and B (14.0-25.0 mg kg-1 DW), by Sheng et al. (2009). These results demonstrate the reliability of our data.

Late April is the early growth stage of 'Seike' and 'Newhall' navel orange fruit. Cell division is prolific at this stage, and the development of fruit occurs mainly due to the increase in cell number. It is well known that cell division requires the synthesis of a high number of nucleic acids and proteins, whereas $\mathrm{N}, \mathrm{P}$, and $\mathrm{S}$ are the important components of nucleic acids and proteins (HAWKESFORD et al., 2012; BRUNETTO et al., 2015). Therefore, the contents of $N, P$, and $S$ were high in the early growth stage of the fruit (Fig. 1). Moreover, numerous enzymes are involved in cell division, while $\mathrm{Mg}, \mathrm{Mn}$, and $\mathrm{Zn}$ usually act as important cofactors or integral components of enzymes (BROADLEY et al., 2012; MAATHUIS; DIATLOFF, 2013; BLOOM; KAMERITSCH, 2017). This can possibly explain the high levels of $\mathrm{Mg}, \mathrm{Mn}$, and $\mathrm{Zn}$ in the fruit in April. Storey and Treeby (2000) also reported high contents of these nutrients in the early development stage of citrus fruits. Compared to the early stage of fruits, a high content 
of $\mathrm{Ca}$ occurred in the later period of fruit development (October 27), possibly because fruit maturation requires $\mathrm{Ca}$ for strengthening of the cell wall (STOREY et al., 2002). The contents of other two elements, $\mathrm{Fe}$ and $\mathrm{Cu}$, were highest in July and May, respectively. It has been documented that $\mathrm{Fe}$ and $\mathrm{Cu}$ are strongly involved in photosynthesis, respiration, $\mathrm{C}$ and $\mathrm{N}$ metabolism, and redox reactions (BROADLEY et al., 2012; BRIAT et al., 2015). However, their functions in fruit growth and development are unclear, and further critical studies need to be conducted in future.

We found that the contents of N, P, K, Fe, Zn, and $\mathrm{Cu}$ were high in the fruit pulp, while the $\mathrm{Ca}, \mathrm{Mn}$, and $\mathrm{B}$ contents were high in the fruit peel. Our results agree well with previous studies. For example, high contents of $\mathrm{P}, \mathrm{K}, \mathrm{Cu}$, and $\mathrm{Fe}$ in the fruit pulp and those of $\mathrm{Ca}, \mathrm{Mn}$, and $\mathrm{B}$ in the fruit peel have been reported in 'Bellamy', 'Newhall', and 'Skaggs Bonanza' navel oranges (STOREY; TREEBY, 2000; XIAO et al., 2007; SHENG et al., 2009). Commonly, the elements that are present in high levels in fruit pulp may be related to fruit quality. When these elements are excessive or deficient, the internal quality of fruit will decrease. For example, $\mathrm{N}$ and $\mathrm{K}$ excess or $\mathrm{P}$ deficiency causes a reduction in the quality of citrus fruit while $\mathrm{N}$ starvation or $\mathrm{P}$ excess can improve fruit quality (MORGAN et al., 2005; ALVA et al., 2006; ZHENG et al., 2015). Moreover, the elements that are present in high levels in the fruit peel, such as $\mathrm{Ca}$ and $\mathrm{B}$, may determine the occurrence of fruit physiological disorders. In citrus, $\mathrm{Ca}$ deficiency causes peel wrinkling and fruit cracking (CHEN et al., 2002; LI; CHEN, 2017; STOREY et al., 2002; TREEBY; STOREY, 2002; MA et al., 2011), and B deficiency results in gum spots in the spongy layer of the rind and an unusually thick and hard peel (XIAO et al., 2006; MESQUITA et al., 2016; WU et al., 2018). Therefore, it is necessary to conduct the proper application of fertilizers in citrus production according to the requirements of the citrus trees with respect to different nutrients in different fruit developmental stages.

As mentioned above, the accumulation of nutrient elements in the fruit reflects the requirements of citrus trees for different mineral nutrients during fruit growth and development. In this study, the accumulation of $\mathrm{N}, \mathrm{P}, \mathrm{K}$, and $\mathrm{Mg}$ from June to July was approximately half of the total accumulation in the whole fruit development stage, and June and July were the high demand times of these nutrients for fruit growth. Thus, N, P, K, and Mg fertilizers should be applied to citrus at this time. However, the transport of rapidly acting fertilizer from the soil to leaves and fruit commonly takes 10 to 15 days, and the time is longer for slow-release fertilizer (ZEKRI et al., 2005; OBREZA; MORGAN, 2008). Therefore, the application of rapidly acting $\mathrm{N}, \mathrm{P}, \mathrm{K}$, and $\mathrm{Mg}$ fertilizers often occurs from late May to early July. The time should be advanced if slow-release fertilizers are used. For the micro-elements, the main accumulation time was from June to September based on our data. In citrus production, the application of micro-elements is mainly through foliar spray, and high absorption efficiency of foliar fertilizer occurs during the initial period of new leaf expansion. Therefore, we recommend the foliar application of micro-elements to new shoots of citrus from June to September. 

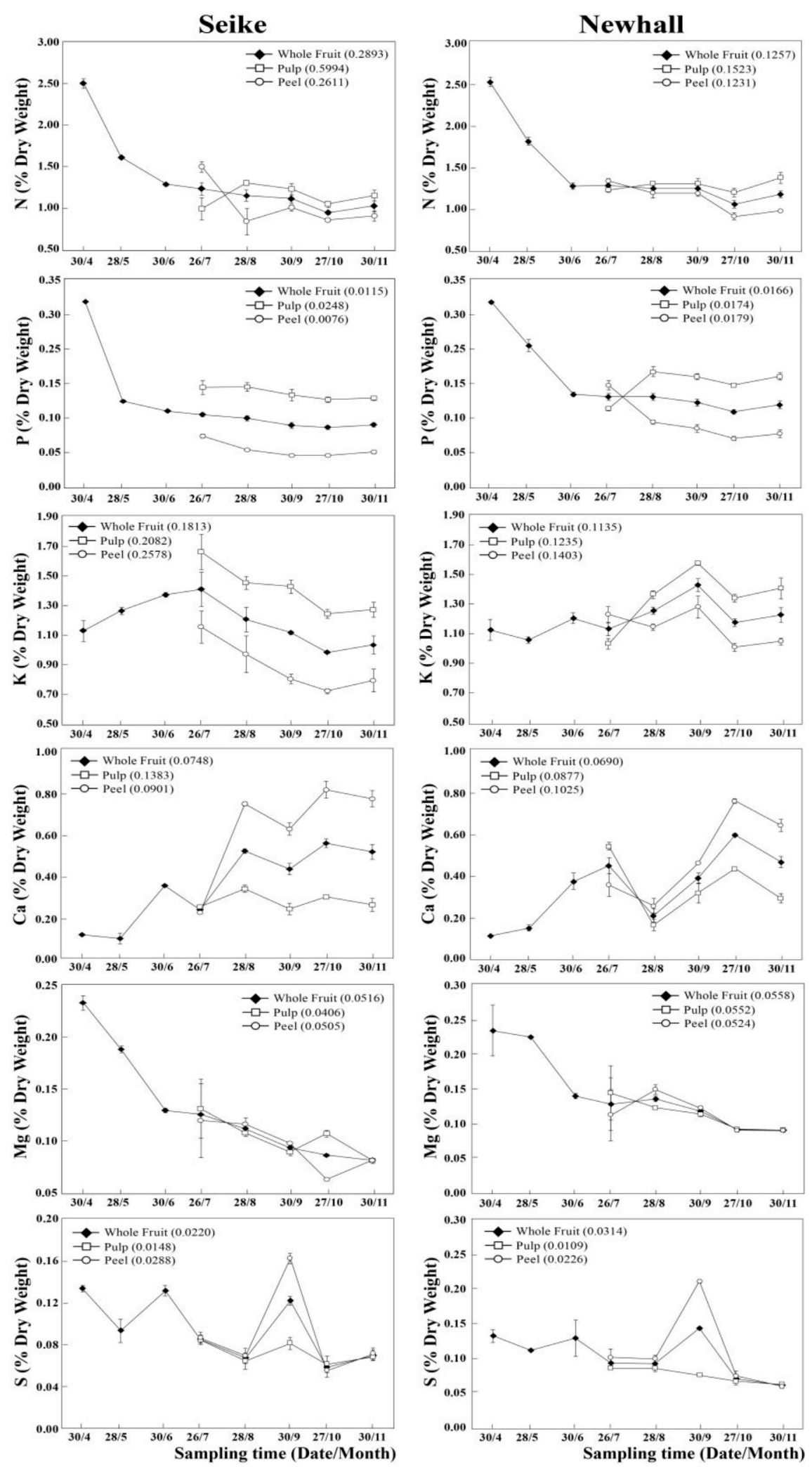

Figure 1- Changes in macro-element (N, P, K, Ca, Mg, and S) concentrations in the whole fruit, fruit pulp, and peel during the fruit development of 'Seike' and 'Newhall' navel oranges. The data are the mean values $\pm \mathrm{SE}$. The number in the parentheses is LSD $(0.05)$ value which indicates the least significant differences test at $P<0.05$. 

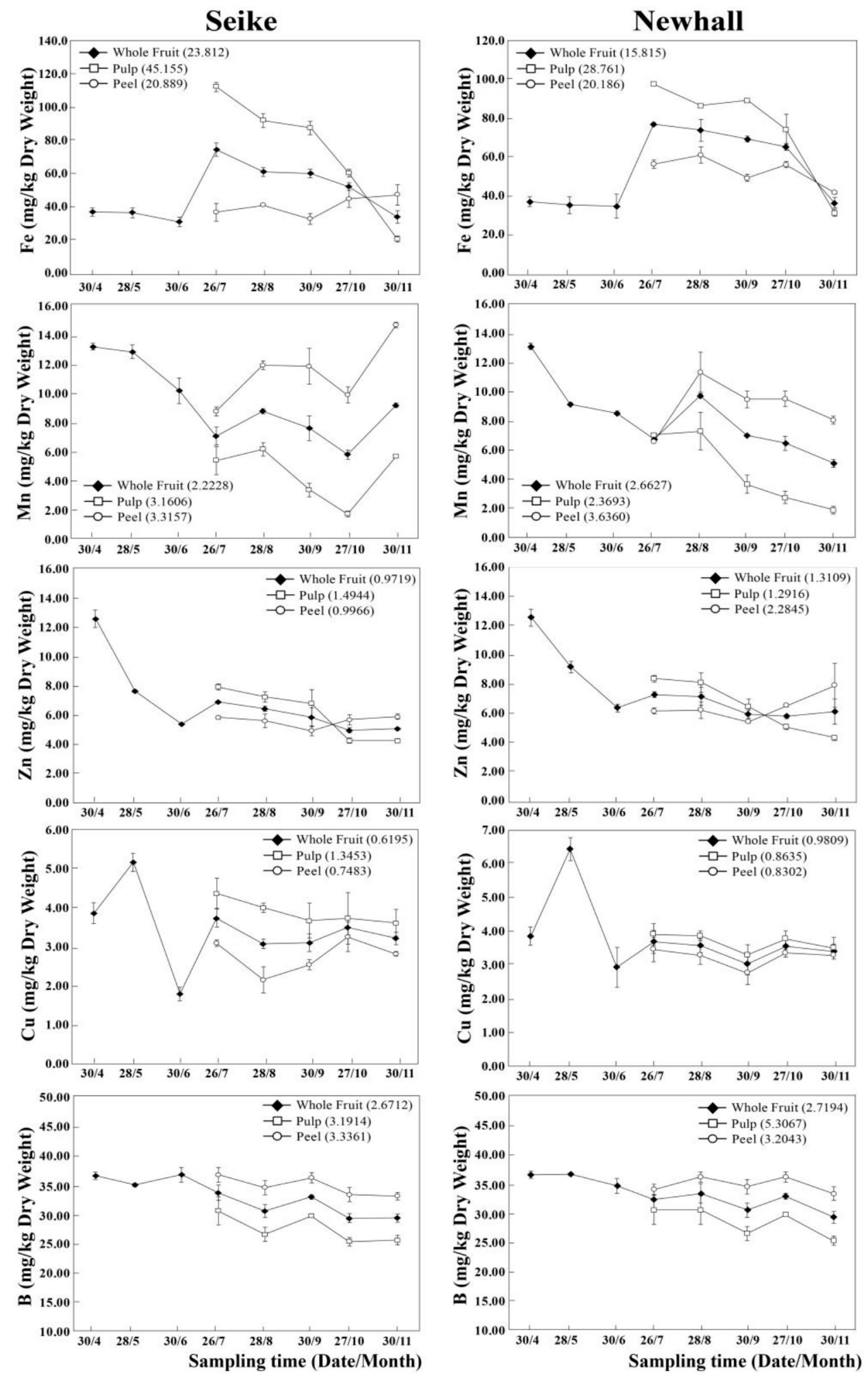

Figure 2- Changes in micro-element ( $\mathrm{Fe}, \mathrm{Mn}, \mathrm{Zn}, \mathrm{Cu}$, and $\mathrm{B}$ ) concentrations in the whole fruit, fruit pulp, and peel during the fruit development of 'Seike' and 'Newhall' navel oranges. The data are the mean values $\pm \mathrm{SE}$. The number in the parentheses is LSD $(0.05)$ value which indicates the least significant differences test at $P<0.05$. 

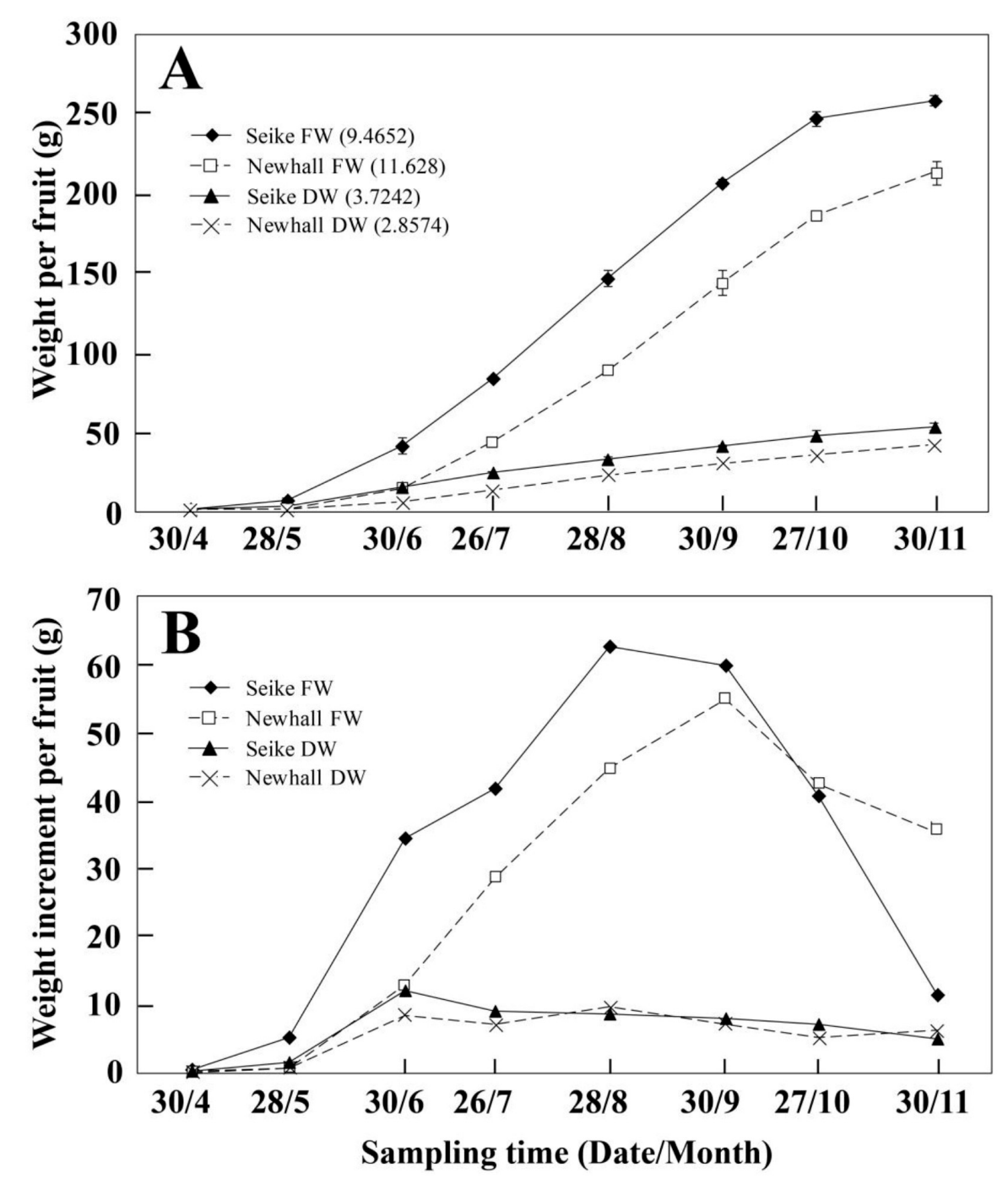

Figure 3- Changes (A) and monthly increase (B) in the fruit fresh weight (FW) and dry weight (DW) during the fruit development of 'Seike' and 'Newhall' navel oranges. The monthly increase is the difference in the FW or DW between two subsequent months. The data are the mean values \pm SE. The number in the parentheses is LSD (0.05) value which indicates the least significant differences test at $P<0.05$. 


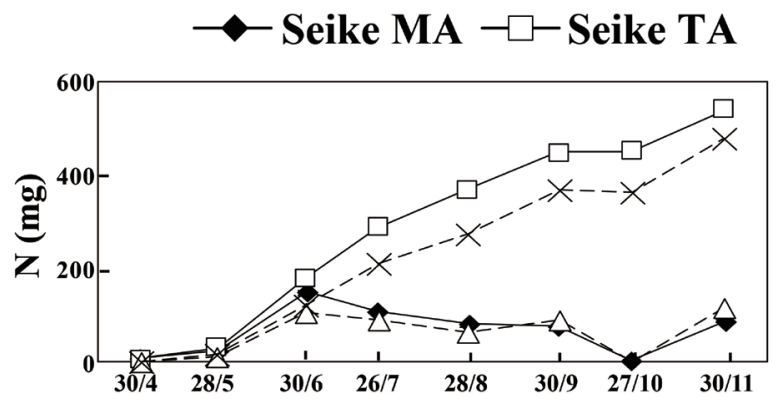

$-A-$ Newhall MA $-\cdot x-$ Newhall TA
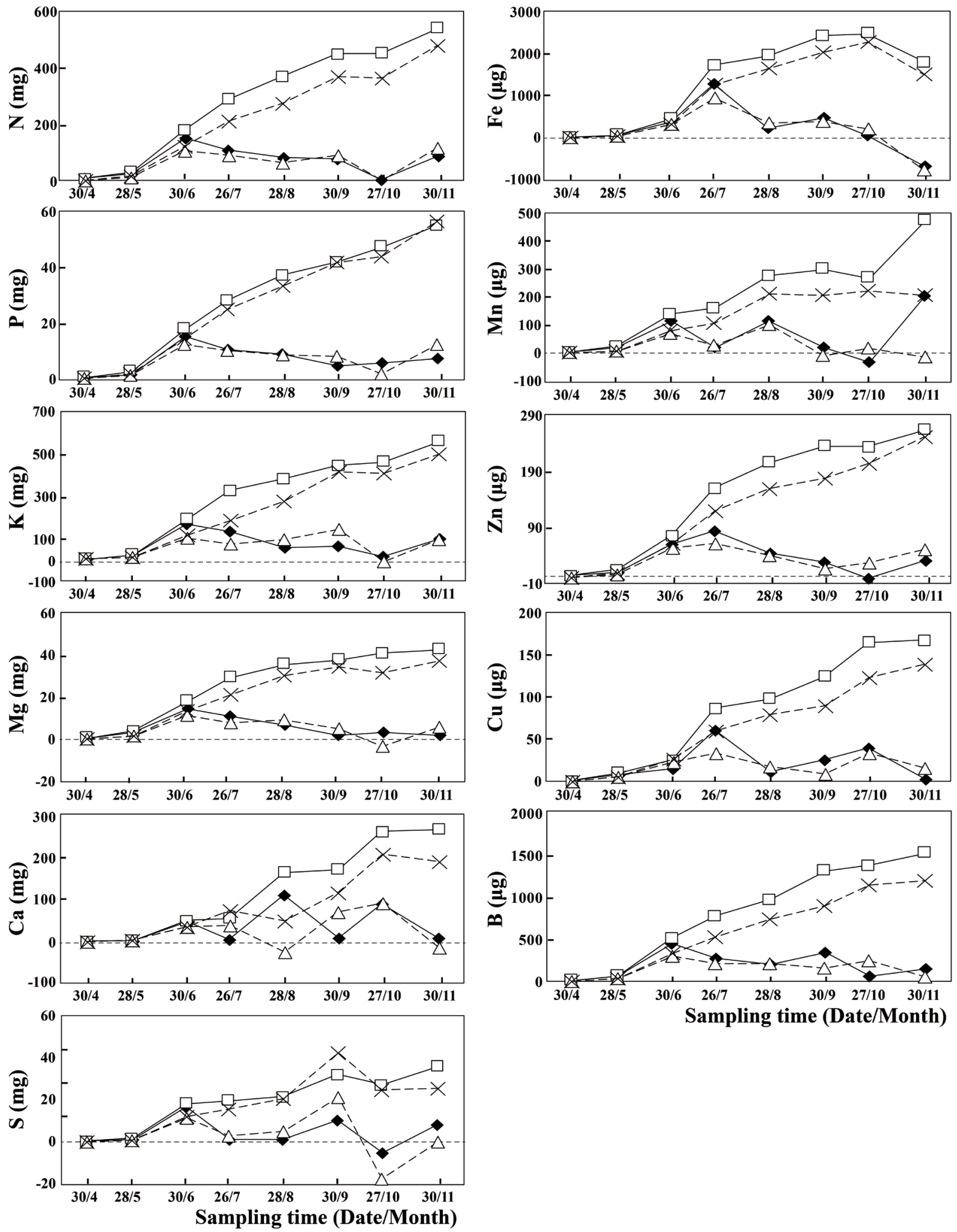

Figure 4- Total accumulation (TA) and monthly accumulation (MA) of macro-elements (mg per fruit) and microelements ( $\mu \mathrm{g}$ per fruit) in the fruits of 'Seike' and 'Newhall' navel oranges during fruit development. TA of nutrient elements $=$ concentration in the whole fruit $\times$ dry weight per fruit, and the MA was calculated as the difference in TA between two subsequent months. 


\section{Conclusions}

'Seike' and 'Newhall' navel oranges had similar variation tendency in the contents and accumulation patterns of mineral nutrients during fruit growth and development. In the two cultivars, the $\mathrm{N}, \mathrm{P}, \mathrm{Mg}, \mathrm{S}, \mathrm{Mn}$, and $\mathrm{Zn}$ contents were high in the young fruit stage (April), the $\mathrm{K}$ and $\mathrm{Fe}$ contents were high in the fruit expansion stage (July and August), and the Ca content was high in the fruit maturation stage (October). In addition, the contents of $\mathrm{N}, \mathrm{P}, \mathrm{K}, \mathrm{Fe}, \mathrm{Zn}$, and $\mathrm{Cu}$ were ranked as fruit pulp $>$ whole fruit $>$ peel, while $\mathrm{Ca}, \mathrm{Mn}$, and $\mathrm{B}$ contents were ranked as fruit peel $>$ whole fruit $>$ fruit pulp. The main accumulation period of $\mathrm{N}, \mathrm{P}, \mathrm{K}$, and $\mathrm{Mg}$ in the fruit was June and July, while for the micro-elements was June to September.

\section{Acknowledgements}

This work was financially supported by the National Key R\&D Program of China (2017YFD0202006, 2017YFD0202002), the National Natural Science Foundation of China (31772280), and the Earmarked Fund for China Agriculture Research System (CARS-27-02A) from Ministry of Agriculture of China.

\section{References}

ALVA, A.K.; PARAMASIVAM, S.; FARES, A.; OBREZA, T.A.; SCHUMANN, A.W. Nitrogen best management practice for citrus trees I. Fruit yield, quality, and leaf nutritional status. Scientia Horticulturae, New York, v.107, p.233-244, 2006.

BLOOM, A.J.; KAMERITSCH, P. Relative association of Rubisco with manganese and magnesium as a regulatory mechanism in plants. Physiologia Plantarum, Copenhagem, v.161, p.545-559, 2017.

BRIAT, J.F.; DUBOS, C.; GAYMARD, F. Iron nutrition, biomass production, and plant product quality. Trends in Plant Science, Cambridge, v.20, p.33-40, 2015.

BROADLEY, M.; BROWN, P.; CAKMAK, I.; RENGEL, Z.; ZHAO, F. Function of nutrients: micronutrients. In: MARSCHNER, P. (ed.). Mineral nutrition of higher plants. Amsterdam: Elsevier, 2012. p.191-248.
BRUNETTO, G.; DE MELO, G.W.B.; TOSELLI, M.; QUARTIERI, M.; TAGLIAVINI, M. The role of mineral nutrition on yields and fruit quality in grapevine, pear and apple. Revista Brasileira de Fruticultura, Jaboticabal, v.37, n.4, p.1089-1104, 2015.

CHEN, J.; LU, X.; YE, Z.; YAO, Q.; WU, L. Study on the relation between mineral nutrition levels and creasing peel in mature orange (in Chinese). Journal of Plant Nutrition and Fertilizers, Lucknow, v.8, p.367-371, 2002.

GONG, Z.T. Chinese soil taxonomy. Beijing: Science Press, 1999.

HAMMAMI, A.; REZGUI, S.; HELLALI, R. Leaf nitrogen and potassium concentrations for optimum fruit production, quality and biomass tree growth in clementine mandarin under Mediterranean climate. Journal of Horticulture \& Forestry, Nairobi, v.2, p.161-170, 2010.

HAWKESFORD, M.; HORST, W.; KICHEY, T.; LAMBERS, H.; SCHJOERRING, J.; SKRUMSAGER, I. Function of Macronutrients. p.135-189. In: MARSCHNER, P. (ed.). Mineral nutrition of higher plants. Amsterdam: Elsevier, 2012.

LI, J.; CHEN, J.Z. Citrus fruit-cracking: causes and occurrence. Horticultural Plant Journal, Amsterdam, v.3, p.255-260, 2017.

MA, X.; PENG L.; CHUN, C.; LING, L.; CAO, L.; JIANG, C.; XIE, F.; ZHANG, W.; GU, Z.; TANG, H. Changes in albedo microstructures and macroelement content in peels of peel pitting 'Navel' oranges (in Chinese). Acta Horticulturae Sinica, Beijing, v.38, p.1857-1864, 2011.

MAATHUIS, F.J.M.; DIATLOFF, E. Roles and functions of plant mineral nutrients. In: MAATHUIS, F. (ed.). Plant mineral nutrients: methods and protocols. Totowa: Humana Press, 2013.

MIR S O LEIMANI, A.; SHAHSAVAR，A.; KHOLDEBARIN, B. Seasonal changes of mineral nutrient concentrations of leaves and stems of 'Kinnow' mandarin trees in relation to alternate bearing. International Journal of Fruit Science, Binghamton, v.14, p.117-132, 2014. 
MORGAN, K.T.; ROUSE, R.E.; ROKA. F.M. Leaf and fruit mineral content and peel thickness of 'Hamlin' orange. Proceedings of the Florida State Horticultural Society, Tallahassee, v.118, p.19-21, 2005.

MESQUITA, G.L.; ZAMBROSI, F.C.B.; TANAKA, F.A.O.; BOARETTO, R.M.; QUAGGIO, J.A.; RIBEIRO, R.V.; MATTOS, D. Anatomical and physiological responses of citrus trees to varying boron availability are dependent on rootstock. Frontiers in Plant Science, Lausanne, v.7, p.224, 2016.

OBREZA, T.A; MORGAN, K.T. Nutrition of Florida citrus trees. Gainesville: Soil and Water Science Department, University of Florida. 2008. (Fact sheet SL253)

PARSONS, L.; BOMAN, B. Best management practices for florida citrus. HortTechnology, Alexandria, v.16, p.389-393, 2006.

RAZZAQ, K.; KHAN, A.S.; MALIK, A.U.; SHAHID, M.; ULLAH, S. Foliar application of zinc influences the leaf mineral status, vegetative and reproductive growth, yield and fruit quality of 'Kinnow' mandarin. Journal of Plant Nutrition, Philadelphia, v.36, p.1479-1495, 2013.

ROCCUZZO, G.; ZANOTELLI, D.; ALLEGRA, M.; GIUFFRIDA, A.; TORRISI, B.F.; LEONARDI, A.; QUINONES, A.; INTRIGLIOLO, F.; TAGLIAVINI, M. Assessing nutrient uptake by field-grown orange trees. European Journal of Agronomy, Amsterdam, v.41, p.73-80, 2012.

SHENG, O.; YAN, X.; PENG, S.A.; DENG, X.X.; FANG, Y.W. Seasonal changes in nutrient concentrations of 'Newhall' and 'Skagg's Bonanza' navel oranges. Communications in Soil Science and Plant Analysis, Philadelphia, v.40, p.3061-3076, 2009.

STOREY, R.; TREEBY, M.T. Seasonal changes in nutrient concentrations of navel orange fruit. Scientia Horticulturae, New York, v.84, p.67-82, 2000.

STOREY, R.; TREEBY, M.T.; DONNA, J.M. Crease: another Ca deficiency-related fruit disorder? The Journal of Horticultural Science and Biotechnology, Ashford, v.77, p.563-571, 2002.
TREEBY, M.T.; STOREY. R. Calcium-spray treatments for ameliorating albedo breakdown in navel oranges. Australian Journal of Experimental Agriculture, Melbourne, v.42, p.495-502, 2002.

WU, X.W.; LU, X.P.; RIAZ, M.; YAN, L.; JIANG, C.C. Boron deficiency and toxicity altered the subcellular structure and cell wall composition architecture in two citrus rootstocks. Scientia Horticulturae, New York, v.238, p.147-154, 2018.

XIAO, J.X.; YANG, X.; PENG, S.A.; DENG, X.X.; FANG, Y.W. Relationship between boron deficiency occurrence and annual changes in contents of boron and sugar of Newhall navel orange. Acta Horticulturae Sinica, Beijing, v.33, p.356-359, 2006.

XIAO, J.X.; YAN, X.; PENG, S.A.; FANG. Y.W. Seasonal changes of mineral nutrients in fruit and leaves of 'Newhall' and 'Skagg's Bonanza' navel oranges. Journal of Plant Nutrition, Philadelphia, v.30, p.671-690, 2007.

ZHENG, C.S.; LAN, X.; TAN, Q.L.; ZHANG, Y.; GUI, H.P.; HU, C.X. Soil application of calcium and magnesium fertilizer influences the fruit pulp mastication characteristics of Nanfeng tangerine (Citrus reticulata Blanco cv.Kinokuni). Scientia Horticulturae, New York, v.191, p.121-126, 2015.

ZEKRI, M.; OBREZA, T.; SCHUMANN, A. Increasing efficiency and reducing costs of citrus nutritional programs. Gainesville: Soil and Water Science Department, University of Florida, 2005. (Fact sheet SL222)

ZHOU, K. B.; GUO, W. W.; XIA, R. X.; WANG, G. Y.; SHEN, T. Effects of two kinds of rootstock on growth and change of nutrient contents in leaf of young tree of navel orange. Plant Nutrition and Fertilizer Science, China, v.10, p.657-662, 2004.

ZHOU, Y.; HE, W.Z.; ZHENG, W.L.; TAN, Q.L.; XIE, Z.Z.; ZHENG, C.S.; HU, C.X. Fruit sugar and organic acid were significantly related to fruit $\mathrm{Mg}$ of six citrus cultivars.

Food Chemistry, London, v.259, p.278-285, 2018. 